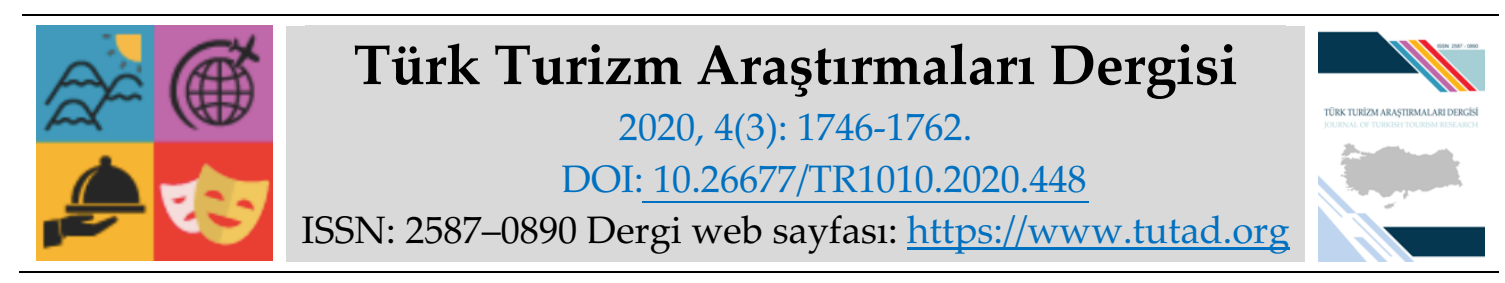

ARASTIRMA MAKALESI

\title{
Seyahat Motivasyonları ve Destinasyon Seçimi: Y ve Z Kuşakları Arasında Bir Karşılaştırma
}

Doç. Dr. Nuran AKŞITT AŞIK, Balıkesir Üniversitesi, Balıkesir Meslek Yüksek Okulu, Balıkesir, e-posta: nuran@balikesir.edu.tr

ORCID: https://orcid.org/0000-0003-0409-7359

Öz

Bu çalışmanın temel amacı, Y kuşağ ile Z kuşağı arasında seyahat motivasyonu ve destinasyon seçimi açısından bir farklılık olup olmadığını araştırmaktır. Araştırma Balıkesir'de ikamet eden 741 kişi ile gerçekleştirilmiştir. Araştırmada nicel araştırma yöntemi benimsenmiş ve veri toplama aracı olarak anket kullanılmıştır. Verilerin analizinde tanımlayıcı istatistiklerden (frekans, yüzde, ortalama, standart sapma) yararlanılmıştır. Seyahat motivasyonu ve destinasyon seçimi açısından $\mathrm{Y}$ ve $\mathrm{Z}$ kuşağı arasında, istatistiksel olarak anlamlı bir fark olup olmadığını belirlemek için verilere Bağımsız Örneklem t-testi uygulanmıştır. Bulgular hem $\mathrm{Y}$ hem de $\mathrm{Z}$ kuşağı katılımcıların bilgi kaynağı olarak internet ve sosyal medyayı önemli gördüklerini ortaya koymaktadır. Ayrıca, her iki nesil için de en önemli seyahat motivasyonu rahatlamadır. Araştırma bulguları, Y kuşağı ile Z kuşağı arasında destinasyon seçimini etkileyen bazı faktörler açısından anlamlı farklılıklar olduğunu ortaya koymaktadır.

Anahtar Kelimeler: Y ve Z kuşağı, Seyahat Motivasyonları, Destinasyon Seçimi.

Makale Gönderme Tarihi: 16.04 .2020

Makale Kabul Tarihi: 05.07.2020

\section{Önerilen Atıf:}

Akşit Aşık, N. (2020). Seyahat Motivasyonları ve Destinasyon Seçimi: Y ve Z Kuşakları Arasında Bir Karşılaştırma, Türk Turizm Araştırmaları Dergisi, 4(3): 1746-1762.

(C) 2020 Türk Turizm Araştırmaları Dergisi. 


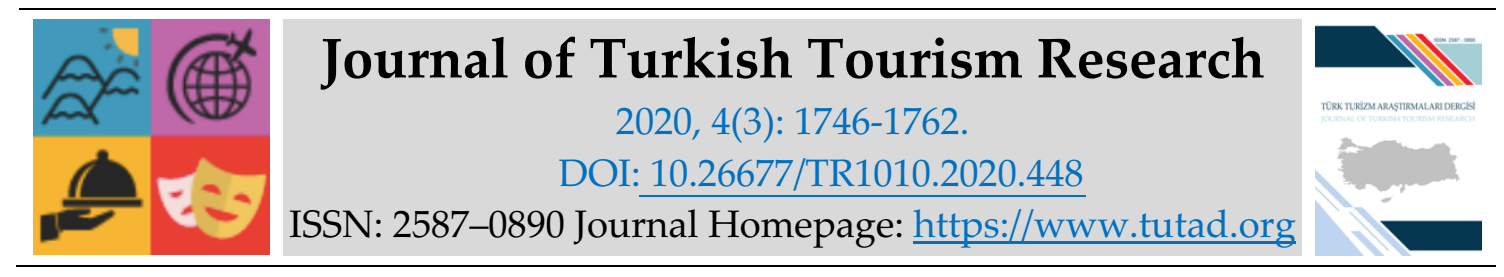

\title{
RESEARCH PAPER
}

\section{Travel Motivations and Destination Choice: A Comparison Between Generations $Y$ and $\mathrm{Z}$}

Associate Prof. Dr. Nuran AKŞITT AŞIK, Balıkesir University, Balıkesir Vocational School, Balıkesir, e-mail: nuran@balikesir.edu.tr

ORCID: https://orcid.org/0000-0003-0409-7359

\begin{abstract}
The main purpose of this study is to investigate whether there is a difference between Generation $\mathrm{Y}$ and Generation $\mathrm{Z}$ in terms of travel motivation and destination choice. The study was conducted on 741 people residing in Balıkesir. In the research the quantitative research method was adopted and the questionnaire as data collection tool was used. Descriptive statistics (frequency, percent, mean, standard deviation) were used in the analysis of the data. In order to determine whether there is a statistically significant difference between Generation $\mathrm{Y}$ and $\mathrm{Z}$ in terms of travel motivation and destination choice, Independent Sample $t$ test was applied to the data. Research findings reveal that internet and social media the most important source of information in their travel decisions both $\mathrm{Y}$ and $\mathrm{Z}$ generation participants. And also, for both generations the most important travel motivation is relaxation. The findings of the study, reveals that there are meaningful differences in terms of some factors affecting destination choice between Generation $\mathrm{Y}$ and Z.
\end{abstract}

Keywords: Generation Y and Z, Travel Motivation, Destination Choice.

Received: 16.04 .2020

Accepted: 05.07.2020

\section{Suggested Citation:}

Akşit Aşık, N. (2020). Travel Motivations and Destination Choice: A Comparison Between Generations Y and Z, Journal of Turkish Tourism Research, 4(3): 1746-1762.

(C) 2020 Türk Turizm Araştırmaları Dergisi. 


\section{Gíriş}

Turizm, toplumsal koşullara göre değişen, dönüşen ve gelişen dinamik bir olgudur. Bu dinamizm içerisinde turistlerin seyahat motivasyonları ve destinasyon seçimi ölçülebilen ya da ölçülemeyen pek çok faktörden etkilenmektedir. Turizm sektöründe faaliyet gösteren işletmelerin sadece bu faktörleri takip etmesi yeterli olmamakta, aynı zamanda yaşanan değişime etkili bir şekilde yanıt vermesi gerekmektedir. Turist davranışlarını anlamak ve etkili yanıt vermek ancak bireyi turistik tüketime yönlendiren seyahat motivasyonlarının öğrenilmesi ile mümkündür (Dwyer vd., 2009: 63). Seyahat motivasyonlarının belirlenmesi, turizm piyasasının anlaşılması ve turistlerin istek ve beklentilerine uygun turistik ürün geliştirilmesi açısından gereklidir (Bansal ve Eiselt, 2004: 388).

Destinasyon seçiminde, bölgenin sosyal, ekonomik koşulları ve kültürel etkinliklerin yanı sıra turistin yaş, cinsiyet, eğitim, gelir durumu gibi demografik değişkenler de etkili olmaktadır (Beerli ve Martin, 2004: 624). Söz konusu demografik değişkenlerin en önemlilerinden birinin yaş faktörü olduğu, özellikle kuşak değişiminin seyahat motivasyonu ve destinasyon seçimi üzerinde etkili olduğu düşünülmektedir.

Bir destinasyonun herkes için her şeye sahip olması mümkün değildir. Bu nedenle, hedef pazarı etkileyen pek çok faktörden biri olan kuşak farklılıklarının değerlendirilmesi gerekmektedir. Buradan hareketle gerçekleştirilen araştırmanın temel amacl, seyahat motivasyonu ve destinasyon seçimi açısından $Y$ kuşağı ile $Z$ kuşağı arasındaki farkı incelemektir. Daha önce $Y$ ve $Z$ kuşağını tüketici karar verme, reklam ve imaj konularında karşılaştıran araştırmalar (Kavalcı ve Ünal, 2016; Serçek ve Serçek, 2017; İnce ve Bozyiğit, 2018; Özden, 2019) olmakla birlikte, seyahat motivasyonu ve destinasyon seçimi bakımından iki kuşağı karşılaştıran bir çalışmaya rastlanmamıştır. Bu nedenle araştırmanın yazına ve turizm pazarlamacılarına katkı sağlaması beklenmektedir.

\section{KURAMSAL ÇERÇEVE ve LITTERATÜR TARAMASI}

Turistlerin tatil kararı üzerinde etkili olan önemli faktörlerden birisi olarak görülen seyahat motivasyonu, "insanlar niçin seyahat eder" sorusunun en önemli cevaplarından birisi olarak görülmektedir (Dunne, 2009: 74). Hatta insan davranışlarının arkasındaki zorlayıcı ve harekete geçirici güç olmasından dolayı seyahat motivasyonu, turist davranışlarını açıklayan en önemli unsur olarak nitelendirilmektedir (Baloğlu ve Uysal, 1996; Kao vd., 2008). Seyahat motivasyonu, uyarılmış bir ihtiyacın tatmin edilmesi için bireyi harekete geçiren, satın alma tercihi üzerinde etkili olan psikolojik ve sosyal faktörleri ifade etmektedir (Solomon vd., 2006; Kotler ve Amstrong, 2012).

Horner ve Swarbrooke'a (2007) göre, seyahat motivasyonu oluşturan faktörler, içsel (hobiler, ilgi alanları, yaşam tarzı, algı ve tutum, inanç ve değerler, geçmiş deneyimler, kişilik vb.) ve dışsal (destinasyonun özellikleri, reklam ve promosyon, iklim, beklentilere uygun ürün ve özellikler vb.) motivasyon unsurları olarak nitelendirilmektedir. İçsel motivasyon bireyin güdü ve ihtiyaçları sonucu oluşurken, dişsal motivasyon üzerinde daha çok destinasyonun özellikleri ve çekicilikleri etkili olmaktadır (Dalgıç ve Birdir, 2015; Kim vd., 2003).

Bireyler destinasyon seçimini istek, ihtiyaç ve amaçları doğrultusunda gerçekleştirmektedir (Pektaş, 2017; Tomić vd., 2014). Ancak ekonomik, sosyal, politik, demografik faktörler de destinasyon seçimi üzerinde etkili olmaktadır (Grimm vd., 2009; Yeoman vd., 2013). Turizm sektörünün büyümesi büyük ölçüde, turist davranışlarını etkileyen sosyo-demografik eğilimlerin iyi anlaşılmasına bağlıdır (Dwyer vd., 2009; Moscardo vd., 2010). Söz konusu demografik faktörlerden biri yaştır. Yapılan araştırmalar, yaşla birlikte ortaya çıkan fiziksel, sosyal ve 
psikolojik değişimlerin bireylerin ihtiyaçlarını da değiştirdiğini ortaya koymaktadır (Lebe, 2006; Aktuğlu ve Temel, 2006). Başka bir ifade ile bireyler, her yaşta farklı tüketim alışkanlıkları içerisine girmekte, destinasyon seçimine yönelik tutum ve algıları farklılık göstermektedir (İçöz, 2001: 80). Bu noktada kuşak farklılıklarının seyahat motivasyonu üzerinde etkili olabileceğini söylemek yanlış olmayacaktır.

İnsanları yaşlarına göre sınıflandıran kuşak teorisine göre, aynı zaman diliminde doğan, aynı koşullarda yaşayan, aynı sorumlulukları ve ortak kişilikleri paylaşan gruplar kuşak olarak tanımlanmaktadır (Ayçiçek, 2013; Kömürcüoğlu, 2014; TDK, 2019). Kuşak teorisine göre, aynı kuşağın üyeleri arasında benzerlik görülürken, farklı kuşakların arasında ise beklenti, ihtiyaç, istek ve hedefler belirgin farklılıklar göstermektedir (Queiri vd., 2014; Torun ve Çetin, 2015). Bu araştırmada ele alınan $\mathrm{Y}$ ve $\mathrm{Z}$ kuşağını tam olarak hangi yılların temsil ettiği konusu halen tartışılmaktadır. Bazı araştırmacılar (Schawbel, 2014; Schroer 2015; Gale, 2015) farklı zaman aralıklarını işaret etmiş olsalar da bu araştırmada da ele alındığı biçimiyle, pek çok araştırmacı 1980-1999 yılları arasında doğanları Y, 2000 yılı ve sonrasında doğanları ise Z kuşağı olarak tanımlamaktadır (Altuntuğ, 2012; Demirkaya vd., 2015).

Y kuşağı (Milenyum kuşağı), diğer kuşaklara göre daha benmerkezci, özgüveni ve beklentileri yüksek, gerçekçi, otoriteden hoşlanmayan, tam tersine özgürlüğüne önem veren, eğitimli bireylerden oluşmaktadır (Avcıkurt, 2018). Marka, eğlence ve arkadaşlığa önem veren ve teknoloji tutkunu olan Y kuşağı, resmi olmayan iletişim kanallarını daha fazla tercih etmektedir (Behrstock-Sherratt ve Coggshall, 2010; Bolton vd., 2010; Perçin ve Mahmutoğulları, 2018). Ayrica bu kuşağın üyeleri, ileri düzeyde düşünebilme ve hızlı bir bilgi edinme sürecine sahip, kolay adapte olabilen, çoklu görev yapabilen ama kolay sıkılan, rahat yaşamaktan hoşlanan, sabırsız, sadakatsiz ve kolay tatmin olmayan kişilerdir (Benckendorff vd., 2010; Rainer ve Rainer, 2011: Lundin, 2018). En genç üyesi 20, en yaşlı üyesi 40'lı yaşlarda olan Y kuşağı, turizm pazarı açısından önem arz etmektedir.

Z kuşağı (Kristal kuşak) ise gelenekçi, aileye değer veren, oto kontrolü ve sorumluluk düzeyi yüksek, yaratıcı ve çoklu karar verme becerisine sahip bireylerden oluşmaktadır (Williams ve Page, 2011; Tulgan, 2013; Southgate, 2017). Teknoloji çağının gençlerini oluşturan Z kuşağ üyelerinin en önemli özellikleri arasında, birden çok sosyal ağa üye olmaları, uzaktan iletişim ve ilişkiye yatkınlıkları ve değişime hızlı uyum sağlamaları yer almaktadır (Altuntuğ, 2012: 206). Küresel beklentileri yüksek, konforuna düşkün, markadan ziyade kalite ve düşük maliyete önem veren, online alışverişten hoşlanan, kampanyaları takip eden, son dakika fırsatlarını araştıran $Z$ kuşağı üyeleri, farklı bir tüketici profili oluşturmaktadır (Ayhün, 2013; Jain vd, 2014; Taş vd., 2017 Postolov vd., 2017; Beall, 2017).

Y ve Z kuşağı üyelerinin özellikleri konusunda bazı araştırmacılar (Greenberg ve Weber, 2008; Palfrey ve Gasser, 2008; Taylor ve Keeter, 2010; Rainer ve Rainer, 2011) iki kuşak arasındaki farklılıkları vurgularken, Furstenberg (2017) iki kuşak arasındaki sınırları belirlemenin güç olduğunu ve aşırı genellemeden kaçınmak gerektiğini belirtmektedir. Yapılan araştırmalar kuşaklara ait özelliklerin destinasyon seçimleri üzerinde etkisi olduğunu ortaya koymaktadır. Bu araştırmalardan biri Barton vd. (2013) tarafından Y kuşağı üzerinde yapılmıştır. Araştırma sonuçları, Y kuşağının fiyata giderek daha duyarlı hale geldiğini ve turistik ürün satın alma kararlarında sosyal ve çevresel faktörlerin etkili olduğunu göstermektedir. Vukic vd. (2015) tarafından yapılan araştırmada ise, $Y$ kuşağının destinasyon seçimini en çok etkileyen faktörlerin fiyat, eğlence ve kültürel olanaklar olduğu belirtilmektedir.

Serçek ve Serçek (2017) X, Y ve Z kuşaklarındaki turistlerin destinasyon imajı algılarını karşılaştırdıkları araştırmada, Y kuşağı katılımcıların tatil yeri seçiminde etkili olan faktörleri manzara/doğal çevre, eğlence olanakları, tarihi ve kültürel çekicilikler olarak sıralamışlardır. 
Aynı araştırmada, Y kuşağının seyahat kararı verirken en çok internetten yararlandığı, katılımcıların yarıdan fazlasının yılda en az bir kez tatile çıtığı ve en fazla eğlenme amacı taşıdıkları vurgulanmaktadır. Veríssimo ve Costa (2018) tarafından Portekiz'de yapılan bir araştırmada hostellerde konaklayan $\mathrm{Y}$ kuşağı üyelerinin beklentileri incelenmiştir. Araştırma sonucunda, Y kuşağı üyelerinin, insanlarla tanışmak, farklı etkinliklere katılmak, yerel deneyimler yaşamak, rahat/evde gibi hissetmek ve paralarının karşılığını almak istedikleri belirlenmiştir.

Migacz ve Petrick (2018) Y kuşağının seyahat motivasyonları, seyahatin algılanan faydalarını inceledikleri araştırmada, Y kuşağı genç ve ilerlemiş yaş grupları olarak ele alınmış ve gelir düzeylerine göre gruplandırılmıştır. Nicel ve nitel yöntemin birlikte kullanıldığı araştırma sonucunda, Y kuşağının homojen olmadığı, genç ve ileri yaş grubunun algı ve güdülerinin farklılık gösterdiği belirlenmiştir.

Cavagnaro vd. (2018) tarafından Hollanda'da yürütülen araştırmada Y kuşağının değer yönelimleri ve turizm deneyimleri incelenmiş ve $Y$ kuşağının homojen olmadığı vurgulanmıştır. Araştırma sonucunda, Y kuşağının seyahati başkalarını öğrenme ve anlama fırsatı olarak gördüğü belirlenmiştir. Monaco (2018) tarafından İtalya'da yürütülen araştırmada, Y ve Z kuşaklarının tatil yeri seçiminde yeni teknolojileri ve özellikle web sayfalarını kullanıp kullanmadıkları incelenmiştir. Araştırma sonucunda, Y kuşağının bilgi toplama ve satın alma kararlarında interneti geleneksel araçlarla (telefon, dergi vb.) birlikte kullandıkları, Z kuşağının neredeyse tamamının web siteleri ve sosyal medyayı tercih ettikleri belirlenmiştir. Styvén ve Foster (2018) tarafından İsveç, İngiltere ve Hindistan' da yürütülen araştırmada, Y ve Z kuşağının seyahat deneyimlerini sosyal medyada paylaşma eğilimleri incelenmiş, her iki kuşağın da seyahat deneyimlerini sosyal medyada paylaşma eğiliminde oldukları tespit edilmiştir.

\section{YÖNTEM}

Nicel araştırma deseni kullanılan araştırma, tarama modelinde gerçekleştirilmiştir. Tarama modeli geçmişte ve halen var olan durumu var olduğu şekilde betimlemeyi amaçlayan bir araştırma yaklaşımıdır (Karasar, 2005).

\section{Ana Kütle ve Örneklem}

Araştırmanın ana kütlesini, hayatında en az bir kez tatile çıkmış ve yaş itibarıyla $Y$ ve $Z$ kuşağına dâhil olan kişiler oluşturmaktadır. Türkiye'nin 2019 yılı nüfus istatistiklerine göre 15-19 yaş grubunda yaklaşık 6,4 milyon, 20-39 yaş aralığında ise yaklaşık 25,7 milyon kişi yer almaktadır (www.nufusu.com). Ana kütlenin 1.000 .000 ve üzerinde olması durumunda $e=0,05$ hata payı ile 384 örneklem büyüklüğünün yeterli olabileceği ifade edilmektedir (Yazıcıŏlu ve Erdoğan, 2004: 50). Bu kapsamda en az 384 kişiye ulaşılması gerektiği belirlenmiş olmakla birlikte, zaman ve parasal maliyetler de dikkate alınarak daha fazla kişiye ulaşılması hedeflenmiştir. Böylece, kolayda örnekleme yoluyla seçilen ve çalışmaya gönüllü olarak katılmayı kabul eden 741 kişi araştırmanın örneklemini oluşturmuştur.

\section{Veri Toplama Aracı}

Veri toplama aracı olarak kullanılan anket 4 bölümden oluşmaktadır. Anketin birinci bölümünde, katılımcıların demografik özelliklerini belirlemeye yönelik 5 soru, ikinci bölümünde destinasyon seçiminde yararlanılan bilgi kaynakları (7 Madde), üçüncü bölümünde seyahat motivasyonları 
(17 madde) ve dördüncü bölümünde destinasyon seçimini etkileyen faktörler (22 madde) yer almaktadır. Seyahat motivasyonları ve destinasyon seçimini etkileyen faktörlere ilişkin maddeler literatür taraması yapılarak oluşturulmuştur (Cha vd., 1995; Baloğlu ve Uysal, 1996; Baloğlu ve Mangaloğlu, 2001; Jang ve Cai, 2002; Kim ve Jogaratman, 2002; Kim vd., 2003, Yoon ve Uysal, 2005; Kim vd. 2006; Mohammad ve Som, 2010). Ölçek maddeleri 5'li Likert tipi (1= Hiç Önemli Değil, $5=$ Çok Önemli) şeklinde düzenlenmiştir. Veriler, Balıkesir il merkezinde yaşayan kişilerden, 13 Mart-15 Haziran 2019 tarihleri arasında yüz yüze görüşme yöntemi ile toplanmıştır.

\section{Verilerin Analizi}

Araştırma verilerinin analizinde SPSS 21.0 istatistik paket programından yararlanılmış, frekans, yüzde, aritmetik ortalama ve standart sapma gibi tanımlayıcı istatistikler kullanılmıştır. Analize geçmeden önce, verilere açıklayıcı faktör analizi yapılmış ve normallik sınaması için Kolmogorov-Smirnov testi uygulanmıştır. Yapılan test sonucunda verilerinin normal dağılım $(p>0,05)$ gösterdiği belirlenmiştir. Böylece veri analizinde parametrik testlerin kullanılabileceği anlaşıldığından, iki bağımsız örneklemden elde edilen ortalamalar arasındaki farkı ölçmek için verilere Bağımsız Örneklem t-testi uygulanmıştır. Test sonuçları değerlendirilmeden önce verilerin homojen olup olmadığını belirlemek için Levene's testinden yararlanılmıştır. Yapılan tüm analizlerde anlamlılık düzeyi $p<0,05$ olarak kabul edilmiştir.

\section{BULGULAR}

\section{Katılımcıların Demografik Özelliklerine İlişkin Bulgular}

Araştırmaya katılanların demografik özelliklerinin dağılımı Tablo 1'de verilmiştir.

Tablo 1. Katılımcıların Demografik Özelliklerinin Dağılımı

\begin{tabular}{|c|c|c|c|c|c|c|c|}
\hline \multirow{2}{*}{ Değişken } & \multirow{2}{*}{ Gruplar } & \multicolumn{2}{|c|}{ Y Kuşağı $(n=393)$} & \multicolumn{2}{|c|}{ Z kuşağ $1(n=348)$} & \multicolumn{2}{|c|}{ Toplam $(n=741)$} \\
\hline & & $\mathrm{f}$ & $\%$ & $\mathrm{f}$ & $\%$ & f & $\%$ \\
\hline \multirow{2}{*}{ Cinsiyet } & Kadın & 181 & 46,1 & 207 & 59,5 & 388 & 52,4 \\
\hline & Erkek & 212 & 53,9 & 141 & 40,5 & 353 & 47,6 \\
\hline \multirow{5}{*}{ Yaş } & $14-16$ & - & - & 104 & 29,9 & 104 & 14,0 \\
\hline & $17-19$ & - & - & 244 & 70,1 & 244 & 32,9 \\
\hline & $20-25$ & 249 & 63,4 & - & - & 249 & 33,7 \\
\hline & $26-31$ & 78 & 19,8 & - & - & 78 & 10,5 \\
\hline & $32-39$ & 66 & 16,8 & - & - & 66 & 8,9 \\
\hline \multirow{4}{*}{ Eğitim Düzeyi } & İlköğretim & 12 & 3,1 & 8 & 2,3 & 20 & 2,7 \\
\hline & Ortaöğretim & 116 & 29,5 & 264 & 75,9 & 380 & 51,3 \\
\hline & Önlisans & 131 & 33,3 & 44 & 12,6 & 175 & 23,6 \\
\hline & Lisans & 134 & 34,1 & 32 & 9,2 & 166 & 22,4 \\
\hline \multirow{4}{*}{$\begin{array}{l}\text { Tatile Çıkma } \\
\text { Sıklığı (Yıllık) }\end{array}$} & Bir Kez & 196 & 49,9 & 207 & 59,5 & 403 & 54,4 \\
\hline & İki Kez & 119 & 30,3 & 98 & 28,2 & 217 & 29,3 \\
\hline & Üç Kez & 55 & 13,9 & 30 & 8,6 & 85 & 11,4 \\
\hline & Dört Kez ve + & 23 & 5,9 & 13 & 3,7 & 36 & 4,9 \\
\hline \multirow{5}{*}{$\begin{array}{l}\text { Ortalama } \\
\text { Gelir/Harcama } \\
\text { (Aylı) }\end{array}$} & 1000 TL ve altı & 80 & 20,4 & 230 & 66,1 & 310 & 41,8 \\
\hline & $1001-2500 \mathrm{TL}$ & 182 & 46,3 & 72 & 20,7 & 254 & 34,3 \\
\hline & $2501-4000$ & 90 & 22,9 & 28 & 8,0 & 118 & 15,9 \\
\hline & $4001-5500$ & 24 & 6,1 & 2 & 0,6 & 26 & 3,5 \\
\hline & 5501 ve üzeri & 17 & 4,3 & 16 & 4,6 & 33 & 4,5 \\
\hline
\end{tabular}


Tablo 1'e göre katılımcıların \%52,4'ü kadın, \%47,6'sı erkektir. Y kuşağı katılımcıların (n=393) $\% 63,4^{\prime}$ ü 20-25 yaş, \%19,8'i 26-31 yaş ve \%16,8'i 32-39 yaş aralığındadır. Z kuşağı katılımcıların $(\mathrm{n}=348)$ ise \%70,1'i 17-19 yaş, \%29,9'u ise 14-16 yaş grubunda yer almaktadır. $Y$ kuşağ katılımcıların \%34,1'i lisans eğitimi, Z kuşağı katılımcıların ise $\% 75,9^{\prime} u$ ortaöğretim eğitimi almıştır/almaktadır. Y kuşağı katılımcıların tatile çıkma sıklığı incelendiğinde, \%49,9'unun yılda bir kez, \%30,3'ünün yılda iki kez tatile çıktığ 1 görülmektedir. Z kuşağ katılımcıların \%59,5'i yılda bir kez, \%28,2'si yılda iki kez tatile çıktığını belirtmiştir. Z kuşağı katılımcıların \%66,1'inin aylık ortalama gelir/harcaması 1000 TL'nin altında olmasının, katılımcıların henüz çalışma hayatında olmamasından kaynaklandığı düşünülmektedir. Y kuşağı katılımcıların \%46,3'ü 1001-2500 TL aralığında aylık geliri/harcaması olduğunu belirtmiştir.

\section{Destinasyon Seçiminde Yararlanılan Bilgi Kaynaklarına Yönelik Bulgular}

Katılımcların destinasyon seçiminde yararlandıkları bilgi kaynaklarına ait ortalama ve standart sapma değerleri Tablo 2'de sunulmuştur.

Tablo 2. Katılımcıların Destinasyon Seçiminde Yararlandıkları Bilgi Kaynaklarının Dağılımı

\begin{tabular}{|l|ccc|ccc|}
\hline \multicolumn{3}{|c|}{} & \multicolumn{3}{|c|}{ Y Kuşağı } & \multicolumn{3}{c|}{ Z Kuşağ1 } \\
\hline Bilgi Kaynağ1 & $\mathbf{n}$ & $\overline{\boldsymbol{x}}$ & S.S. & $\mathbf{N}$ & $\overline{\boldsymbol{x}}$ & S.S. \\
\hline İnternet (Web Siteleri) & 393 & 3,89 & 1,39 & 348 & 3,92 & 1,41 \\
\hline Sosyal Medya & 393 & 3,77 & 1,07 & 348 & 4,18 & 0,63 \\
\hline Gazete/Dergi/Broşür & 393 & 2,51 & 1,39 & 348 & 2,77 & 1,61 \\
\hline Arkadaş/Akraba tavsiyesi & 393 & 3,64 & 1,33 & 348 & 3,20 & 1,56 \\
\hline Turizm Danışma Büroları & 393 & 2,18 & 1,33 & 348 & 2,34 & 1,47 \\
\hline Seyahat Acentası & 393 & 3,29 & 1,35 & 348 & 3,28 & 1,49 \\
\hline Diğgr (Şehir rehberi, Fuar, Festival vb.) & 393 & 2,24 & 1,38 & 348 & 2,45 & 1,49 \\
\hline
\end{tabular}

Tablo 2'ye göre $\mathrm{Y}$ kuşağı katılımclar destinasyon seçiminde en çok internetten $(\bar{x}=3,89)$ yararlanmakta, bunu sosyal medya $(\bar{x}=3,77)$ ve arkadaş/akraba tavsiyesi $(\bar{x}=3,64)$ izlemektedir. Destinasyon seçiminde Z kuşağı katılımcıların en çok yararlandıkları bilgi kaynakları ise sosyal medya $(\bar{x}=4,18)$, internet $(\bar{x}=3,92)$ ve arkadaş/akraba tavsiyesi $(\bar{x}=3,20)$ olarak siralanmaktadır. $Y$ $(\bar{x}=2,18)$ ve $Z \quad(\bar{x}=2,34)$ kuşağı katılımcların en az yararlandıkları bilgi kaynağı ise turizm danışma bürolarıdır.

\section{Geçerlilik ve Güvenilirlik Analizi Bulguları}

Verilerin analize uygunluğunu test etmek için öncelikle seyahat motivasyonu ölçeğine Varimax dönüşümlü temel bileşenler analizi uygulanmıştır. Faktör sayısının tespitinde, bir maddenin bir faktöre boyutlanabilmesi için ilgili faktör yükünün en az 0,40 düzeyinde olmasına karar verilmiştir. Yapılan faktör analizi sonucunda, tüm maddelerin özdeğeri 1'den büyük ve toplam varyansın \%62,9'unu açıklayan tek bir faktör altında toplandığı belirlenmiştir. Analiz sonucunda Kaiser-Mayer-Olkin (KMO) örneklem yeterliliği 0,88 olarak hesaplanmış, Bartlett's küresellik testi $(6260,896)$ sonucunun anlamlı $(\mathrm{p}<0,01)$ olduğu belirlenmiştir. Bartlett's küresellik testinin anlamlı olması, verilerin çok değişkenli normal dağılımdan geldiğini ve faktör analizine devam edilebileceğini ortaya koymaktadır (Nakip 2003; Çokluk vd., 2012). Ayrıca ölçeğin Cronbach's alfa değeri $(\alpha=0,89)$ ölçeğin güvenilirliğinin iyi düzeyde olduğunu göstermektedir.

$Y$ ve $Z$ kuşağı katılımcıların seyahat motivasyonlarına ilişkin, ortalama, standart sapma değerleri ve faktör analizi sonuçları Tablo 3 'te verilmiştir. 
Tablo 3. Y ve Z Kuşağı Katılımcıların Seyahat Motivasyonlarına İlişkin Ortalama, Standart Sapma Değerleri ve Faktör Analizi Bulguları

\begin{tabular}{|c|c|c|c|c|c|c|c|}
\hline \multirow[t]{2}{*}{ Maddeler } & \multicolumn{3}{|c|}{ Y Kuşağ1 } & \multicolumn{3}{|c|}{ Z Kuşağ1 } & \multirow{2}{*}{$\begin{array}{l}\text { Faktör } \\
\text { Yükleri }\end{array}$} \\
\hline & $\mathbf{n}$ & $\bar{x}$ & S.S. & $\mathbf{n}$ & $\bar{x}$ & S.S. & \\
\hline Günlük yaşamın rutininden kaçmak & 393 & 4,15 & 1,04 & 348 & 3,92 & 1,14 & 0,79 \\
\hline Ruhsal ve fiziksel olarak rahatlamak & 393 & 4,26 & 1,11 & 348 & 4,18 & 1,10 & 0,80 \\
\hline Kalabalıktan uzaklaşmak & 393 & 3,92 & 1,09 & 348 & 3,97 & 1,09 & 0,65 \\
\hline Heyecan bulmak & 393 & 3,99 & 1,05 & 348 & 3,91 & 1,13 & 0,77 \\
\hline Macera yaşamak & 393 & 4,13 & 1,17 & 348 & 4,00 & 1,31 & 0,81 \\
\hline $\begin{array}{l}\text { Değişik kültür ve yaşam şekillerini } \\
\text { tecrübe etmek }\end{array}$ & 393 & 3,89 & 1,14 & 348 & 3,90 & 1,18 & 0,73 \\
\hline Eğlenmek & 393 & 4,23 & 0,98 & 348 & 4,17 & 1,00 & 0,75 \\
\hline Yeni şeyler öğrenmek, bilgiyi arttırmak & 393 & 3,87 & 0,94 & 348 & 3,97 & 0,96 & 0,59 \\
\hline Entelektüel olarak zenginleşmek & 393 & 3,80 & 0,97 & 348 & 3,91 & 1,02 & 0,68 \\
\hline Yeni/değişik yerlerde bulunmak & 393 & 4,09 & 0,98 & 348 & 4,07 & 1,07 & 0,74 \\
\hline Benzer ilgilere sahip kişilerle tanışmak & 393 & 3,63 & 1,10 & 348 & 3,61 & 1,14 & 0,71 \\
\hline Yakın arkadaşlık geliştirmek & 393 & 3,58 & 1,19 & 348 & 3,59 & 1,18 & 0,61 \\
\hline $\begin{array}{l}\text { Arkadaşlarımın bulunmadığı yerlere } \\
\text { gitmek }\end{array}$ & 393 & 3,09 & 1,26 & 348 & 3,62 & 1,11 & 0,60 \\
\hline Arkadaşlarıma seyahatimi anlatmak & 393 & 3,65 & 1,04 & 348 & 3,73 & 1,07 & 0,63 \\
\hline Ünlü kişilerin gittiği yerlere gitmek & 393 & 3,10 & 1,31 & 348 & 3,10 & 1,34 & 0,64 \\
\hline Erkek/Kız arkadaş bulmak & 393 & 3,39 & 1,25 & 348 & 3,34 & 1,35 & 0,71 \\
\hline Yeni yiyecek ve içecekleri denemek & 393 & 3,92 & 1,11 & 348 & 3,93 & 1,10 & 0,76 \\
\hline \multicolumn{8}{|c|}{$\begin{array}{l}\text { Varimax rotasyonlu temel bileşenler analizi. } \\
\text { Açıklanan toplam varyans: \% 62,9 } \\
\text { Kaiser-Meyer-Olkin örneklem yeterliliği:0,87; Bartlett's küresellik testi: } x^{2}: 6260,896 ; p<0,01 \\
\text { Cronbach's Alpha: 0,89 } \\
\text { Yanıt kategorileri: } \\
\text { 1:Hiç önemli değil, 2: Biraz önemli, 3: Ne önemli ne önemsiz, 4: Önemli, 5: Çok önemli }\end{array}$} \\
\hline
\end{tabular}

Tablo 3'te yer alan ortalama ve standart sapma değerleri incelendiğinde, gerek $Y$ kuşağ $(\bar{x}=4,26)$, gerek $Z$ kuşağ $(\bar{x}=4,18)$ katılımcların ortalaması en yüksek seyahat motivasyonunun "Ruhsal ve fiziksel olarak rahatlamak" olduğu görülmektedir. İkinci sırada yer alan motivasyon faktörü "Eğlenmek" ifadesine ait olup, ortalama puan Y kuşağı için $\bar{x}=4,23$, Z kuşağı için ise $\bar{x}=4,17$ olarak hesaplanmıştır. Her iki değişkenin de, $\mathrm{Y}$ ve $\mathrm{Z}$ kuşağı katılımcılar açısından seyahat motivasyonunu artıran bir unsur olduğu görülmektedir.

Y kuşağı katılımcıların diğer motivasyon faktörleri sırasıyla "Günlük yaşamın rutininden kaçmak" $(\bar{x}=4,15)$ ve "Macera yaşamak" $(\bar{x}=4,13)$ olarak sıralanmaktadır. Y kuşağı katılımcıların en düşük puan ortalaması ise "Arkadaşlarımın bulunmadığı yerlere gitmek" ifadesine $(\bar{x}=3,09)$ aittir. Z kuşağı katılımcıların "Yeni/değişik yerlerde bulunmak" ( $\bar{x}=4,07)$ ve "Macera yaşamak" $(\bar{x}=4,00)$ ifadeleri için puan ortalamasının önemli düzeyde olduğu görülmektedir. Ayrıca $Z$ kuşağı için "Ünlü kişilerin gittiği yerlere gitmek" $(\bar{x}=3,10)$ ifadesinin puan ortalaması en düşük düzeydedir.

$\mathrm{Y}$ ve $\mathrm{Z}$ kuşağı katılımcıların destinasyon seçimini etkileyen faktörlere yönelik tutumunu belirleme amacı taşıyan veri setinin faktör analizine uygunluğunu test eden KMO değeri 0,88 ve Bartlett's küresellik testi $\left(x^{2}=5676,044 ; p<0,05\right)$ sonuçları da, verilerin faktör analizine uygun olduğunu ortaya koymaktadır. Yapılan faktör analizi sonucunda, destinasyon seçimine yönelik 
ölçek maddelerinin özdeğeri 1'den büyük olan üç faktör altında toplandığı belirlenmiştir. Ayrıca ölçeğin Cronbach's alfa değeri 0,89 olarak hesaplanmıştır. Bu sonuç ölçeğin güvenilirliğinin iyi düzeyde olduğunu göstermektedir. Analiz bulguları Tablo 4'te verilmektedir.

Tablo 4. Y ve Z Kuşağı Katılımcıların Destinasyon Seçimini Etkileyen Faktörlere Yönelik Ortalama, Standart Sapma Değerleri ve Faktör Analizi Bulguları

\begin{tabular}{|c|c|c|c|c|c|c|c|}
\hline \multirow[t]{2}{*}{ Maddeler } & \multicolumn{3}{|c|}{ Y Kuşağ1 } & \multicolumn{3}{|c|}{ Z kuşağ1 } & \multirow{2}{*}{$\begin{array}{l}\text { Faktör } \\
\text { Yükleri }\end{array}$} \\
\hline & $\mathbf{n}$ & $\bar{x}$ & S.S. & $\mathbf{n}$ & $\bar{x}$ & S.S. & \\
\hline $\begin{array}{l}\text { Verilen paraya karşılık iyi bir değer } \\
\text { elde etmek }\end{array}$ & 393 & 4,05 & 1,12 & 348 & 4,10 & 0,69 & 0,64 \\
\hline Güzel manzara ve doğal çekicilikler & 393 & 4,08 & 1,07 & 348 & 4,19 & 0,90 & 0,68 \\
\hline İklim & 393 & 3,69 & 1,04 & 348 & 3,83 & 0,87 & 0,58 \\
\hline Yöresel yemekler & 393 & 4,09 & 0,95 & 348 & 4,24 & 0,73 & 0,67 \\
\hline Tarihi ve arkeolojik çekicilikler & 393 & 3,92 & 1,05 & 348 & 4,11 & 0,95 & 0,62 \\
\hline Popüler olması & 393 & 3,55 & 1,07 & 348 & 3,80 & 1,05 & 0,68 \\
\hline Altyapı kalitesi & 393 & 3,72 & 1,01 & 348 & 3,85 & 1,00 & 0,56 \\
\hline Güvenli olması & 393 & 4,06 & 0,85 & 348 & 4,02 & 0,96 & 0,58 \\
\hline Bozulmamış ve kirlenmemiş çevre & 393 & 4,00 & 0,99 & 348 & 4,14 & 0,82 & 0,58 \\
\hline Standart hijyen ve temizlik & 393 & 3,84 & 1,13 & 348 & 3,88 & 1,01 & 0,68 \\
\hline Uygun fiyat & 393 & 4,25 & 0,89 & 348 & 4,27 & 1,01 & 0,57 \\
\hline İlginç ve arkadaş canlısı yer & 393 & 3,91 & 1,04 & 348 & 3,83 & 1,05 & 0,51 \\
\hline Farklı kültürel çekicilikler & 393 & 4,02 & 1,06 & 348 & 4,06 & 0,98 & 0,54 \\
\hline Kolay ulaşım & 393 & 3,98 & 1,03 & 348 & 4,11 & 1,00 & 0,57 \\
\hline Aile ile gidilebilir olması & 393 & 3,86 & 1,17 & 348 & 4,06 & 0,99 & 0,67 \\
\hline Her şey dâhil tatil olanakları & 393 & 4,02 & 1,06 & 348 & 4,04 & 1,03 & 0,66 \\
\hline Mükemmel plajlar & 393 & 3,92 & 1,05 & 348 & 3,97 & 1,03 & 0,67 \\
\hline Uygun konaklama olanakları & 393 & 3,86 & 1,07 & 348 & 3,99 & 1,10 & 0,56 \\
\hline Egzotik atmosfer & 393 & 3,64 & 1,12 & 348 & 3,81 & 1,03 & 0,51 \\
\hline $\begin{array}{l}\text { Yaşadığım yerden daha ucuza } \\
\text { alışveriş imkânı }\end{array}$ & 393 & 3,90 & 1,14 & 348 & 4,09 & 1,03 & 0,62 \\
\hline Güzel gece hayatı ve eğlence & 393 & 4,00 & 1,06 & 348 & 4,05 & 0,99 & 0,76 \\
\hline Macera aktiviteleri & 393 & 3,81 & 1,05 & 348 & 4,05 & 0,83 & 0,54 \\
\hline \multicolumn{8}{|c|}{$\begin{array}{l}\text { Varimax rotasyonlu temel bileşenler analizi. } \\
\text { Açıklanan toplam varyans: \% 59,3 } \\
\text { Kaiser-Meyer-Olkin örneklem yeterliliği:0,88; Bartlett's küresellik testi: } x^{2}: 5676,044 ; p<0,01 \\
\text { Cronbach's Alpha: 0,89 } \\
\text { Yanıt kategorileri: } \\
\text { 1:Hiç önemli değil, 2: Biraz önemli, 3: Ne önemli ne önemsiz, 4: Önemli, 5: Çok önemli }\end{array}$} \\
\hline
\end{tabular}

Tablo 4'te görüldüğü üzere, destinasyon seçiminde etkili olan ilk üç faktör $Y$ ve $Z$ kuşağ1 katılımcılar açısından ortaktır. Destinasyon seçimini etkileyen faktörlerden "Uygun fiyat" hem Y kuşağı $(\bar{x}=4,25)$, hem de $Z(\bar{x}=4,27)$ kuşağı katılımcılar için en yüksek puan ortalamasına sahiptir. Destinasyon seçimini etkileyen ikinci faktör olan "Yöresel yemekler" için Y kuşağının puan ortalaması $\bar{x}=4,08, Z$ kuşağının puan ortalaması ise $\bar{x}=4,24$ olarak hesaplanmıştır. En önemli üçüncü faktör "Güzel manzara ve doğal çekicilikler" değişkenine olup, Z kuşağı katılımcıların puan ortalaması $(\bar{x}=4,19), Y$ kuşağ 1 katılımclara $(\bar{x}=4,08)$ göre daha yüksektir.

Y kuşağ $1(\bar{x}=3,55)$ ve $Z$ kuşağ $1(\bar{x}=3,80)$ katılımcılar için en düşük puan ortalamasına sahip olan faktör destinasyonun popülerliğidir. 


\section{Bağımsız Örneklem t-Testi (Independent Samples t-Test) Bulguları}

Araştırmaya katılan $\mathrm{Y}$ ve Z kuşağı üyelerinin destinasyon seçiminde yararlandıkları bilgi kaynakları arasındaki farkın anlamlı olup olmadığını belirlemek için yapılan bağımsız örneklem t-testi bulguları Tablo 5 'te verilmektedir.

Tablo 5. Y ve Z Kuşağı Katılımcıların Destinasyon Seçiminde Yararlandıkları Bilgi Kaynakları Arasındaki Farkın Anlamlılığını Test Etmek İçin Yapılan Bağımsız Örneklem t-Testi Sonuçları

\begin{tabular}{|c|c|c|c|c|c|c|c|c|c|}
\hline \multirow{2}{*}{ Değişken } & \multirow{2}{*}{ Gruplar } & \multirow{2}{*}{$\mathbf{n}$} & \multirow{2}{*}{$\bar{x}$} & \multirow{2}{*}{$\begin{array}{l}\text { S. } \\
\text { S. }\end{array}$} & \multicolumn{2}{|c|}{ Levene's Test } & \multicolumn{3}{|c|}{ t-Testi } \\
\hline & & & & & F & $p$ & $t$ & Sd & $p$ \\
\hline \multirow[t]{2}{*}{ Sosyal medya } & Y Kuşağ & 393 & 3,77 & 1,07 & \multirow{2}{*}{1,135} & \multirow{2}{*}{0,24} & \multirow{2}{*}{6,373} & \multirow{2}{*}{739} & \multirow{2}{*}{0,00} \\
\hline & Z Kuşağ1 & 348 & 4,18 & 0,63 & & & & & \\
\hline \multirow{2}{*}{$\begin{array}{l}\text { Arkadaş/Akraba } \\
\text { tavsiyesi }\end{array}$} & Y Kuşağ1 & 393 & 3,64 & 1,33 & \multirow{2}{*}{0,947} & \multirow{2}{*}{0,11} & \multirow{2}{*}{3,199} & \multirow{2}{*}{739} & \multirow{2}{*}{0,00} \\
\hline & Z Kuşağ & 348 & 3,20 & 1,56 & & & & & \\
\hline
\end{tabular}

Tablo 5'te görüldüğü gibi, destinasyon seçiminde yararlanılan bilgi kaynaklarından sosyal medya ve arkadaş/akraba tavsiyesi değişkenleri, $\mathrm{Y}$ ve $\mathrm{Z}$ kuşağı katılımcılar açısından istatistiksel olarak anlamlı $(\mathrm{p}<0,05)$ bir farklılık göstermektedir. Levene's testi sütunu incelendiğinde değişkenlere ait varyansların homojen olduğu $(p>0,05)$ görülmektedir.

Elde edilen bulgular incelendiğinde, sosyal medya kullanımı açısından gruplar arasındaki farklılık istatistiksel olarak anlamlı bulunmuştur $\left(t_{(739)}=6,373 ; p<0,05\right)$. Buna göre bilgi edinme kaynağı olarak sosyal medya kullanan Z kuşağı katılımcıların ortalaması $(\bar{x}=4,18)$, Y kuşağ katılımcıların $(\bar{x}=3,77)$ puan ortalamasından daha yüksektir. Ayrıca arkadaş/akraba tavsiyesi değişkeni açısından da, gruplar arasındaki farkın anlamlı olduğu $\left(t_{(739)}=3,199 ; p<0,05\right)$ ve $Y$ kuşağ 1 katılımcların $(\bar{x}=3,64)$ arkadaş/akraba tavsiyesine $Z$ kuşağ 1 katılımclara $(\bar{x}=3,20)$ göre daha fazla önem verdikleri belirlenmiştir.

Tablo 6. Katılımcıların Seyahat Motivasyonları Arasındaki Farkın Anlamlılığını Test Etmek Amacıyla Yapılan Bağımsız Örneklem t-Testi Bulguları

\begin{tabular}{|c|c|c|c|c|c|c|c|c|c|}
\hline \multirow[t]{2}{*}{ İfadeler } & \multirow{2}{*}{ Gruplar } & \multirow{2}{*}{$\mathbf{n}$} & \multirow{2}{*}{$\bar{x}$} & \multirow{2}{*}{ S.S. } & \multicolumn{2}{|c|}{ Levene's Test } & \multicolumn{3}{|c|}{ t-Testi } \\
\hline & & & & & $\mathbf{F}$ & p & $t$ & Sd & $\mathrm{p}$ \\
\hline $\begin{array}{l}\text { Günlük yaşamın } \\
\text { rutininden kaçmak }\end{array}$ & $\begin{array}{l}\text { Y } \\
\text { Kuşağ1 } \\
Z \\
\text { Kuşağ } 1\end{array}$ & $\begin{array}{l}393 \\
348\end{array}$ & $\begin{array}{l}4,15 \\
3,92\end{array}$ & $\begin{array}{l}1,04 \\
1,14\end{array}$ & 1,542 & 0,22 & 2,861 & 739 & 0,00 \\
\hline $\begin{array}{l}\text { Arkadaşlarımın } \\
\text { bulunmadı̆̆ yerlere } \\
\text { gitmek }\end{array}$ & $\begin{array}{l}\text { Y } \\
\text { Kuşağ1 } \\
Z \\
\text { Kuşağ }\end{array}$ & $\begin{array}{l}393 \\
348\end{array}$ & $\begin{array}{l}3,09 \\
3,62\end{array}$ & $\begin{array}{l}1,26 \\
1,11\end{array}$ & 3,401 & 0,17 & 6,068 & 739 & 0,00 \\
\hline
\end{tabular}

Tablo 6'da görüldüğü üzere, katılımcıların seyahat motivasyonları kuşak değişkenine göre istatistiksel olarak anlamlı $(\mathrm{p}<0,05)$ bir farklılık göstermektedir. Levene's testi sütunu incelendiğinde değişkenlere ait varyansların homojen olduğu $(p>0,05)$ görülmektedir. Buna göre "Günlük yaşamın rutininden kaçmak" $\left(\mathrm{t}_{(739)}=2,861 ; \mathrm{p}<0,05\right)$ ifadesi açısından $\mathrm{Y}$ kuşağ 1 katılımcıların ortalamaları $(\bar{x}=4,15)$, Z kuşağı katılımcılara $(\bar{x}=3,92)$ göre daha yüksektir. "Arkadaşlarımın bulunmadığ yerlere gitmek" ( $\left.\mathrm{t}_{(739)}=6,068 ; \mathrm{p}<0,05\right)$ ifadesi için ise $Z$ kuşağ 1 
katılımcıların puan ortalamalarının $(\bar{x}=3,62)$, Y kuşağı katılımcılara göre $(\bar{x}=3,09)$ daha yüksek olduğu belirlenmiştir.

Tablo 7. Katılımcıların Destinasyon Seçimini Etkileyen Faktörler Arasındaki Farkın Anlamlılığını Test Etmek İçin Yapılan Bağımsız Örneklem t-Testi Sonuçları

\begin{tabular}{|c|c|c|c|c|c|c|c|c|c|}
\hline \multirow[t]{2}{*}{ Değişkenler } & \multirow{2}{*}{ Gruplar } & \multirow[t]{2}{*}{$\mathbf{N}$} & \multirow[t]{2}{*}{$\bar{x}$} & \multirow{2}{*}{ S.S. } & \multicolumn{2}{|c|}{$\begin{array}{c}\text { Levene's } \\
\text { Test } \\
\end{array}$} & \multicolumn{3}{|c|}{ t-Testi } \\
\hline & & & & & $\mathbf{F}$ & $\mathrm{p}$ & $\mathbf{t}$ & Sd & $\mathbf{P}$ \\
\hline \multirow{2}{*}{ Yöresel yemekler } & Y Kuşağ1 & 393 & 4,09 & 0,95 & \multirow{2}{*}{1,948} & \multirow{2}{*}{0,33} & \multirow{2}{*}{2,531} & \multirow{2}{*}{739} & \multirow{2}{*}{0,01} \\
\hline & Z Kuşağ1 & 348 & 4,24 & 0,73 & & & & & \\
\hline \multirow{2}{*}{$\begin{array}{l}\text { Bozulmamış ve } \\
\text { kirlenmemiş çevre }\end{array}$} & Y Kuşağ1 & 393 & 4,00 & 0,99 & \multirow{2}{*}{0,970} & \multirow{2}{*}{0,32} & \multirow{2}{*}{1,199} & \multirow{2}{*}{739} & \multirow{2}{*}{0,04} \\
\hline & Z Kuşağı & 348 & 4,14 & 0,82 & & & & & \\
\hline \multirow{2}{*}{$\begin{array}{l}\text { Tarihi ve arkeolojik } \\
\text { çekicilikler }\end{array}$} & Y Kuşağ & 393 & 3,92 & 1,05 & \multirow{2}{*}{0,344} & \multirow{2}{*}{0,56} & \multirow{2}{*}{3,297} & \multirow{2}{*}{739} & \multirow{2}{*}{0,01} \\
\hline & Z Kuşağ1 & 348 & 4,11 & 0,95 & & & & & \\
\hline \multirow{2}{*}{ Popüler olması } & Y Kuşağ1 & 393 & 3,55 & 1,07 & \multirow{2}{*}{0,443} & \multirow{2}{*}{0,51} & \multirow{2}{*}{ 3,295 } & \multirow{2}{*}{739} & \multirow{2}{*}{0,01} \\
\hline & Z Kuşağ1 & 348 & 3,80 & 1,05 & & & & & \\
\hline \multirow{2}{*}{$\begin{array}{l}\text { Aile ile gidilebilir } \\
\text { olması }\end{array}$} & Y Kuşağ1 & 393 & 3,86 & 1,17 & \multirow{2}{*}{2,052} & \multirow{2}{*}{0,13} & \multirow{2}{*}{5,083} & & \\
\hline & Z Kuşağ1 & 348 & 4,06 & 0,99 & & & & 739 & 0,00 \\
\hline Fozotik atmosfer & Y Kuşağ1 & 393 & 3,64 & 1,12 & 0846 & 034 & 2117 & 739 & 003 \\
\hline & Z Kuşağg & 348 & 3,81 & 1,03 & 0,040 & 0,04 & $2,11 /$ & 139 & 0,00 \\
\hline Yaşadığım yerden daha & Y Kuşağ1 & 393 & 3,90 & 1,14 & 6,056 & 0,14 & 2,423 & 739 & 0,01 \\
\hline ucuza alışveriş imkânı & Z Kuşağ1 & 348 & 4,09 & 1,03 & 0,050 & 0,14 & $2,4 \angle 0$ & 139 & 0,01 \\
\hline Ма & Y Kuşağ1 & 393 & 3,81 & 1,05 & 3473 & 0.19 & 3.372 & 739 & 0.01 \\
\hline Miace & Z Kuşağ & 348 & 4,05 & 0,83 & & & & & 0,01 \\
\hline
\end{tabular}

Araştırmaya katılan $\mathrm{Y}$ ve $\mathrm{Z}$ kuşağı katılımcıların destinasyon seçimini etkileyen faktörler arasında anlamlı bir farklılık olup olmadığını belirlemek amacıyla yapılan bağımsız örneklem ttesti sonuçları Tablo 7'de verilmiştir. Öncelikle grup varyanslarının homojen olup olmadığını görmek için yapılan Levene's testi sütununda yer alan destinasyon seçimini etkileyen faktörlere ait $\mathrm{p}$ değerinin $0,05^{\prime}$ ten büyük olması varyansların homojen olduğunu göstermektedir.

Destinasyon seçimini etkileyen faktörlerden "Yöresel yemekler" açısından Y ve Z kuşakları arasındaki farkın anlamlı olduğu gözlenmiştir $\left(t_{(739)}=2,531 ; p<0,05\right)$. Buna göre $Z$ kuşağı üyelerinin grup ortalaması $(\bar{x}=4,24)$, Y kuşağı üyelerinin grup ortalamasından $(\bar{x}=4,09)$ daha yüksektir. "Bozulmamış ve kirlenmemiş çevre" değişkeni açısından da, iki kuşak arasındaki fark istatistiksel olarak anlamlıdır $\left(\mathrm{t}_{(739)}=1,199 ; \mathrm{p}<0,05\right)$. $\mathrm{Z}$ kuşağ doğal çekiciliklere ait ortalama, Y kuşağı üyelerine $(\bar{x}=4,00)$ göre daha yüksektir. Destinasyonun tarihi ve kültürel çekiciliklere sahip olması açısından da, iki kuşak arasındaki fark anlamlı $\left(t_{(739)=}\right.$ 3,297; $\mathrm{p}<0,05)$ olup, tarihi ve arkeolojik çekicilikler $\mathrm{Z}$ kuşağı üyeleri için $(\bar{x}=4,11)$, Y kuşağı üyelerine $(\bar{x}=3,92)$ göre daha önemlidir.

Destinasyon seçiminde etkili olan faktörlerden, destinasyonun popüler olması bakımından iki

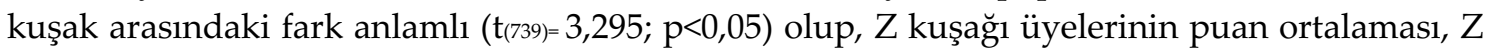
kuşağı üyelerine göre daha yüksektir. Destinasyonun "Aile ile gidilebilir olması" $Z$ kuşağı üyeleri $(\bar{x}=4,06)$ için $Y$ kuşağ 1 üyelerine $(\bar{x}=3,86)$ göre daha önemli bulunduğu için gruplar arasındaki fark $(t / 739)=5,083 ; p<0,05)$ anlamlıdır. Destinasyon seçiminde egzotik atmosfer faktörü de gruplar arasında anlamlı bir farklılık göstermektedir $\left(t_{(739)}=2,117 ; p<0,05\right)$. $Z$ kuşağı üyelerinin puan ortalaması $(\bar{x}=3,81)$, Y kuşağı üyelerine göre $(\bar{x}=3,64)$ daha yüksektir. 
"Yaşadığım yerden daha ucuza alışveriş imkânı" açısından da gruplar arasındaki fark anlamlı $\left(t_{(739)}=2,423 ; \mathrm{p}<0,05\right)$ olup, $\mathrm{Z}$ kuşağ 1 üyelerinin grup ortalaması $(\bar{x}=3,90)$, Y kuşağ 1 üyelerine $(\bar{x}=4,09)$ göre daha yüksektir. "Macera aktiviteleri" maddesi de gruplar arasında anlamlı bir farklılık (t(739)= 3,372; $\mathrm{p}<0,05)$ göstermektedir. Buna göre macera aktivitelerine $\mathrm{Z}$ kuşağı üyeleri $(\bar{x}=4,05), Y$ kuşağ üyelerine $(\bar{x}=3,81)$ göre daha fazla önem vermektedir.

\section{SONUÇ ve ÖNERILER}

Turizm pazarının en büyük hedef kitlesini oluşturan $Y$ ve Z kuşağının özelliklerinin belirlenmesi, kuşak farklılıklarını anlamak ve doğru yorumlamak açısından önemlidir. Buradan hareketle gerçekleştirilen araştırmanın temel amacı, seyahat motivasyonu ve destinasyon seçimi açısından $\mathrm{Y}$ ve $\mathrm{Z}$ kuşakları arasındaki farkın incelenmesidir. Amaca uygun olarak 741 kişi üzerinde yürütülen araştırmanın bulguları, destinasyon seçiminde hem $Y$ hem de $Z$ kuşağının bilgi kaynağı olarak en çok internet ve sosyal medyayı kullandıklarını göstermektedir. Ancak, Y kuşağı üyeleri bilgi kaynağı olarak daha çok web sayfalarını kullanırken, Z kuşağı üyeleri sosyal medyayı tercih etmektedir. Elde edilen bulgular daha önce yapılan araştırmaların (Monaco, 2018; Serçek ve Serçek, 2017; Styvén ve Foster, 2018) sonuçları ile paralellik göstermektedir.

Destinasyon seçiminde kullanılan bilgi kaynakları arasındaki bu fark, destinasyon pazarlaması açısından önemlidir. Bu doğrultuda her iki kuşağına yönelik pazarlama faaliyetlerinde, sosyal medya pazarlaması ve mobil pazarlama, web siteleri, online broşür ve katalog vb. dijital pazarlama araçlarının etkin olarak kullanılması gerekmektedir. Ancak başkalarının yaşamını sosyal ağlardan anlık olarak takip eden ve kendi deneyimlerini de aynı yolla aktaran Z kuşağı başkalarının deneyimlerine önem vermektedir. Bu nedenle $Z$ kuşağına ulaşmak için, videolar, kurumsal sosyal ağlar, blog ve forumlar (Influencer Marketing), sanal ya da arttırılmış gerçeklik uygulamalarının kullanılması destinasyon pazarlaması açısından çok daha etkili olacaktır.

Araştırmadan elde edilen bulgular, $Y$ ve $Z$ kuşağı üyelerinin en önemli iki seyahat motivasyonunun benzerlik gösterdiğini ortaya koymaktadır. Her iki kuşak üzerinde de ruhsal/fiziksel olarak rahatlama ve eğlenme en önemli motivasyon faktörlerini teşkil etmektedir. Y kuşağı için günlük yaşamın rutininden kaçma, macera yaşama, yeni/değişik yerlerde bulunma, heyecan, kalabalıktan uzaklaşma, yeni yiyecek ve içecekleri deneme diğer motivasyon unsurlarını oluşturmaktadır. Z kuşağının motivasyon unsurları ise, yeni/değişik yerlerde bulunma, macera yaşama, yeni şeyler öğrenme, kalabalıktan uzaklaşma, yeni yiyecek ve içecekler deneme ve entelektüel olarak zenginleşme ve heyecan olarak sıralanmaktadır.

Bulgular, Y ve Z kuşağı katılımcıların destinasyon seçimini en çok etkileyen ilk üç faktörün aynı olduğunu göstermektedir. Söz konusu faktörler, fiyat, yöresel yemekler, güzel manzara ve doğal çekicilikler olarak sıralanmaktadır. Bu durum, Y ve Z kuşağı üyelerinin fiyata duyarlı, farklı tatları deneme arzusu yüksek ve doğal çekiciliklere önem veren bireylerden oluştuğunu göstermektedir. Elde edilen bulgular daha önce yapılan bazı araştırmaların sonuçları ile benzerlik göstermektedir (Vukic vd., 2015; Barton vd.,2013; Serçek ve Serçek, 2017).

Y kuşağının destinasyon seçiminde önem verdiği diğer unsurlar, destinasyonun güvenli olması, verilen paraya karşılık iyi bir değer elde etme, farklı kültürel çekicilikler, her şey dâhil olanakları, gece hayatı ve eğlence olarak sıralanmaktadır. Z kuşağı ise destinasyon seçiminde bozulmamış ve kirlenmemiş çevre, tarihi ve arkeolojik çekicilikler, kolay ulaşım, verilen paraya karşılık iyi bir değer elde etme, ucuza alışveriş olanakları, farklı kültürel çekicilikler ve aile ile seyahate uygunluk unsurlarına daha fazla önem vermektedir. Araştırma bulguları, Y ve Z kuşağının destinasyon seçimini etkileyen faktörler açısından benzerlikler olmakla birlikte, bu faktörlerin önem düzeyinin değiştiğini ortaya koymaktadır. 
Destinasyon seçimini etkileyen faktörlerden, yöresel yemekler, bozulmamış ve kirlenmemiş çevre, tarihi ve arkeolojik çekicilikler, destinasyonun popülerliği, aile ile gidilebilir olması, egzotik atmosfer, ucuz alışveriş olanakları ve macera aktivitelerine ait Z kuşağının puan ortalamaları $\mathrm{Y}$ kuşağına göre daha yüksektir. Elde edilen bulgular değerlendirildiğinde $\mathrm{Y}$ kuşağının Z kuşağının doğaya duyarlı, farklı tarihi ve kültürel çekiciliklere ilgi duyan, yabancı/uzak ülkeleri merak eden ve maceraperest bir yapıya sahip olduğunu ortaya koymaktadır. Ayrıca alışverişi seven ve popüler kültürden etkilenen $\mathrm{Z}$ kuşağının destinasyon seçiminde, Y kuşağına göre daha bilinçli ve seçici davrandığı, harcadığı paranın karşılığında iyi bir değer elde etmek istediği ve beklentilerinin daha yüksek olduğu söylenebilir.

Araştırma bulguları, destinasyon pazarlamacıları açısından önem taşıyan bazı ipuçları içermektedir. Buna göre, her iki kuşak da fiyata duyarlı olup, pazarlama iletişiminde ulaşım, konaklama ve alışveriş olanakları açısından mutlaka uygun fiyat vurgusu yapılmalıdır. Benzer biçimde hem $\mathrm{Y}$ hem de $\mathrm{Z}$ kuşağı rahatlama, eğlenme motivasyonlarına önem vermekte, yerel unsurlar ve doğal çekicilikleri önemli bulmaktadır. Dolayısıyla $\mathrm{Y}$ ve $\mathrm{Z}$ kuşağı turistleri destinasyona çekmek isteyen turizm profesyonelleri, rahatlama, zevk, eğlence gibi hazc1 motivasyonları öne çıkarmalı, pazarlama mesajlarında yerel kültür, doğal çevre, farklı macera aktiviteleri, rekreasyon ve eğlence olanaklarına vurgu yapmalıdır. Ayrıca özellikle Z kuşağına yönelik pazarlama iletişiminde bilgiden ziyade, duygu ve deneyimi öne çıkaran mesajların daha faydalı olacağı düşünülmektedir.

Araştırmadan elde edilen bulgular genel olarak değerlendirildiğinde, seyahat motivasyonları ile destinasyon seçimi açısından $\mathrm{Y}$ ve $\mathrm{Z}$ kuşağı arasındaki farklılıklar kadar benzerlikler de dikkat çekmektedir. Elde edilen bu sonucun, örneklemin \%80,6'sının 14-25 yaş aralığında olmasından kaynaklandığı düşünülmektedir. Araştırma verilerinin en önemli kısıtını oluşturan bu durum verilerin genellenmesini de engellemektedir. Ancak turizm sektörünün $Y$ ve $Z$ kuşaklarına yönelik gerçekleştireceği kuşak pazarlaması açısından iki kuşak arasındaki farklılıkların bilinmesi önem taşımaktadır. Bu noktada araştırma bulgularının, gelecekte yapılacak akademik çalışmalara ve uygulayıcılara $\mathrm{Y}$ ve $\mathrm{Z}$ kuşaklarının temel özellikleri, motivasyon unsurları, beklentileri ve yeni turistik ürünlerin geliştirilmesi konusunda ön bilgi oluşturacağ düşünülmektedir. Son olarak, gelecekte yapılacak araştırmalarda, genç ve ileri yaş grubunda yer alan $\mathrm{Y}$ ve $\mathrm{Z}$ kuşağı üyelerinin karşılaştırılmasının, iki kuşak arasındaki farkların belirlenmesi açısından daha yararlı olacağı öngörülmektedir.

\section{KAYNAKÇA}

Aktuğlu, K. I. ve Temel, A. (2006). Tüketiciler Markaları Nasıl Tercih Ediyor? (Kamu Sektörü Çalışanlarının Giysi Markalarını Tercihini Etkileyen Faktörlere Yönelik Bir Araştırma), Selçuk Üniversitesi Sosyal Bilimler Enstitüsü Dergisi, (15): 43-59.

Altuntuğ, N. (2012). Kuşaktan Kuşağa Tüketim Olgusu ve Geleceğin Tüketici Profili, Organizasyon ve Yönetim Bilimleri Dergisi, 4(1): 203-212.

Avcıkurt, C. (2018). Y Kuşağı Turistler veya Y "Kâşifleri". [Online] https://www.turizmajansi. com/haber/y-kusagi-turistler-veya-y-kasiflerih28067/ [Erişim Tarihi: 12. 11. 2019].

Ayçiçek, M. (2013). Çocuk ve Demokratik Eğitim Kuşaklar Arası Çatı̧̧ma ve Aile İçi Demokrasinin Önemi. İstanbul: Gün Matbaacılık Yayın Ltd. Şti.

Ayhün, E. S. (2013). Kuşaklar Arasındaki Farklılıklar ve Örgütsel Yansımaları, Ekonomi ve Yönetim Araştırmaları Dergisi, 2(1): 93-112. 
Baloğlu Ş. and Uysal M. (1996) Market Segments of Push and Pull Motivations: A Canonical Correlation Approach, International Journal of Contemporary Hospitality Management, 8(3): 32-38.

Baloğlu, Ş. and Mangaloğlu, M. (2001). Tourism Destination Images of Turkey, Egypt, Greece, and Italy As Perceived By US-Based Tour Operators and Travel Agents, Tourism Management, 22(1): 1-9.

Bansal, H. and Eiselt, H. A. (2004). Exploratory Research of Tourist Motivations and Planning, Tourism Management, 25(3): 387-396.

Barton, C., Haywood, J., Jhunjhunwala, P. and Bhatia, V. (2013). Traveling with Millennials, BCGThe Boston Consulting Group. [Online] https://www.bcg.com/documents/file129974.pdf. [Erişim Tarihi: 05. 11. 2019].

Beall, G. (2017). 8 Key Differences between Gen Z and Millennials, The Huffington Post. 5(2): 597605. [Online] https://www.huffpost.com/entry/8-key-differences-between_b_12814200. [Erişim Tarihi: 03. 01. 2020].

Beerli A. and Martin, D. J. (2004). Tourist Characteristics and the Perceived Image of Tourist Destinations: A Quantitative Analysis- A Case Study of Lanzarote, Spain, Tourism Management, 25(5): 623-636.

Behrstock-Sherratt, E. and Coggshall, J. G. (2010). Realizing the Promise of Generation Y, Educational Leadership, 67(8): 28-34.

Benckendorff, P. Moscardo, G. and Pendergast, D. (Eds.) (2010). Tourism and Generation Y. Wallingford, Oxfordshire: Cabi International.

Bolton, R. N., Parasuraman, A., Hoefnagels, A., Migchels, N., Kabadayı, S., Gruber, T., Komarova, Y. and Solnet, D. (2013). Understanding Generation Y and Their Use of Social Media: A Review and Research Agenda, Journal of Service Management, 24(3): 245-267.

Cavagnaro, E., Staffieri, S. and Postma, A. (2018). Understanding Millennials' Tourism Experience: Values and Meaning to Travel as a Key for Identifying Target Clusters for Youth (Sustainable) Tourism, Journal of Tourism Futures. [Online] https://www.emerald.com/insight/ content/doi/10.1108/JTF-12-2017-0058/full/html [Erişim Tarihi: 03. 01. 2020].

Cha, S, Mccleary, K. W. and Uysal, M. (1995). Travel Motivations of Japanese Overseas Travelers: A Factor-Cluster Segmentation Approach, Journal of Travel Research, 34(1): 33-39.

Çokluk, Ö., Şekercioğlu, G. ve Büyüköztürk, Ş. (2012). Sosyal Bilimler İçin Çok Değişkenli İstatistik, SPSS ve LISREL Uygulamaları. Ankara: Pegem Akademi.

Dalgıç, A. ve Birdir, K. (2015). Yayla Turizmine Katılan Turistlerin Seyahat Motivasyonları, Algılanan Değer, Tatmin Düzeyleri ve Sadakatleri Üzerine Bir Araştırma, Journal of Tourism and Gastronomy Studies, 3(3): 3-17.

Demirkaya, H., Akdemir, A., Karaman, E. ve Atan, Ö. (2015). Kuşakların Yönetim Politikası Beklentilerinin Araştırılması, İ̧̧letme Araştırmaları Dergisi, 7(1): 186-204.

Dunne, G. (2009). Motivation and Decision Making in City Break Travel. Saarbrucken, Germany: VDM Publishing.

Dwyer, L., Edwards, D., Mistilis, N., Roman, C. and Scott, N. (2009). Destination and Enterprise Management for a Tourism Future, Tourism Management, 30(1): 63-74. 
Furstenberg, F. (2017). The Use and Abuse of Millennials as an Analytic Category, Council on Contemporary Families. [Online] https://contemporaryfamilies.org/8-furstenberg-millennials-anal ytic-category/ [Erişim Tarihi: 15.03.2020].

Gale: F. (2015). Forget Millennials: Are You Ready for Generation Z. Chief Learning Officer, 14(7): $38-48$.

Greenberg, E. H. and Weber, K. (2008). Generation We: How Millennial Youth are Taking over America and Changing our World Forever. Emeryville: Pachatusan.

Grimm, B., Lohmann, M., Heinsohn, K., Richter, C. and Metzler, D. (2009). The Impact of Demographic Change on Tourism and Conclusions for Tourism Policy. A Study Commissioned by the Federal Ministry of Economics and Technology. [Online] http://citeseerx.ist.psu.edu/viewdoc/ download?doi=10.1.1.475.9999\&rep=rep1\&type=pdf. [Erişim Tarihi: 05. 01. 2020].

Horner, S. and Swarbrooke, J. (2007). Consumer Behavior in Tourism. Oxford: Elsevier.

https://www.nufusu.com/turkiye-nufusu-yas-gruplari [Erişim Tarihi: 05.03.2020].

İçöz, O. (2001). Turizm İşletmelerinde Pazarlama, İlkeler ve Uygulamalar. (2. Baskı), Ankara: Turhan Yayınevi.

İnce, M. ve Bozyiğit, S. (2018). Tüketicilerin Instagram Reklamlarına Karşı Tutumlarının Satın Alma Davranışları Üzerindeki Etkisi: Y Ve Z Kuşağı Üzerine Bir Araştırma, Beykoz Akademi Dergisi, 6(2): 39-56.

Jain, V., Vatsa, R. and Jagani, K. (2014). Exploring Generation Z's Purchase Behavior Towards Luxury Apparel: A Conceptual Framework, Romanian Journal of Marketing, 2: 18-29.

Jang, C. and Cai, L. A. (2002). Travel Motivations and Destination Choice: A Study of British Outbound Market, Journal of Travel \& Tourism Marketing, 13(3): 111- 133.

Kao, M. C., Patterson, I., Scott, N. and Li, C. K. (2008). Motivations and Satisfactions of Taiwanese Tourists Who Visit Australia: An Exploratory Study. Journal of Travel and Tourism Marketing, 24 (1): 17-33.

Karasar, N. (2005). Bilimsel Araştırma Yöntemi, İlkeler, Teknikler. İstanbul: Nobel Yayınları.

Kavalcı, K. ve Ünal, S. (2016). Y ve Z Kuşaklarının Öğrenme Stilleri ve Tüketici Karar Verme Tarzları Açısından Karşılaştırılması, Journal of Graduate School of Social Sciences, 20(3): 1033-1050.

Kim, K. Y. and Jogaratnam, G. (2002). Travel Motivations: A Comparative Study of Asian International and Domestic American College Students, Journal of Travel and Tourism Marketing, 13(4): 61-82.

Kim, K., Noh, J. and Jogaratnam, G. (2006). Multi-Destination Segmentation Based on Push and Pull Motives: Pleasure Trips of Students at a U.S. University, Journal of Travel \& Tourism Marketing, 21(2-3): 19-32.

Kim, S. S., Lee, C. K. and Klenosky, D. B. (2003). The Influence of Push and Pull Factors at Korean National Parks, Tourism Management, 24(2): 169-180.

Kotler, P. and Armstrong, G. (2012). Principles of Marketing. (14th Edition), New Jearsey: Pearson Education Inc.

Kömürcüoğlu, H. (2014). Y Kuşağını Anlamak. Ankara: Kanguru Yayınları. 
Lebe, F. (2006). Tüketici Davranış ve Tercihlerinin Analizi: Erzurum İçin Bir Uygulama, Yayımlanmamış Yüksek Lisans Tezi, Atatürk Üniversitesi Sosyal Bilimler Enstitüsü, İktisat Ana Bilim Dalı, Erzurum.

Lundin, K. (2018). Post-Millennial Marketing: How to Market Effectively to Generation Z, https://www.crowdspring.com/blog/marketing-generation-z/ [Erişim Tarihi: 13. 02. 2020].

Migacz, S. J. and Petrick, J. F. (2018). Millennials: America's Cash Cow is Not Necessarily A Herd, Journal of Tourism Futures, 4(1): 16-30.

Mohammad, B. A. M. A. H. and Som, A. P. M. (2010). An Analysis of Push and Pull Travel Motivations of Foreign Tourists to Jordan, International Journal of Business and Management, 5(12): 41-50.

Monaco, S. (2018). Tourism and the New Generations: Emerging Trends and Social Implications in Italy, Journal of Tourism Futures, 4(1): 7-15.

Nakip, M. (2003). Pazarlama Araştırmaları Teknikler ve (SPSS Destekli) Uygulamalar. (1. Baskı), Ankara: Seçkin Yayıncllık.

Özden, A. T. (2019). Pozitif Algının ve Tüketici Karar Verme Tarzlarının Y ve Z Kuşakları Açısından Karşılaştırılması, Gazi İktisat ve İşletme Dergisi, 5(1): 1-20.

Palfrey, J. and Gasser, U. (2008). Born Digital. Understanding the First Generation of Digital Natives. Basic Books, NY, [Online] http://pages.uoregon.edu/koopman/courses_readings/phil123-net/ identity/pal frey-gasser_born-digital.pdf. [Erişim Tarihi: 20. 12. 2019].

Pektaş, F. (2017). Seyahat Motivasyonunu Oluşturan İtici ve Çekici Faktörlerin Tüketici Temelli Destinasyon Değeri Üzerine Etkisi, Yayımlanmamış Doktora Tezi, Nevşehir Hacı Bektaş Veli Üniversitesi, Sosyal Bilimler Enstitüsü, Nevşehir.

Perçin, N. Ş. ve Mahmutoğulları, D. (2018). Y Kuşağının Turizm Endüstrisine Etkisi. (Ed.), Ş. Aydın ve M. Boz, Turizmde Güncel Konu ve Eğilimler II içinde (s. 127-147), Ankara: Detay Yayıncilik.

Postolov, K., Magdinceva-Sopova, M. and Janeska-Iliev, A. (2017). E-learning in the Hands of Generation Y and Z, 2nd Business \& Entrepreneurial Economics Conference, 24-26 May 2017, Brijuni National Park, Republic of Croatia. [Online] https://hrcak. srce.hr/ [Erişim Tarihi: 20. 12. 2019].

Queiri, A., Yusoff, W. F. W. and Dwaikat, N. (2014). Generation-Y Employees' Turnover: WorkValues Fit Perspective, International Journal of Business and Management, 9(11): 199-213.

Rainer, T. and Rainer, J. (2011). The Millennials: Connecting to America's Largest Generation. Nashville: B\&H Publishing Group.

Schawbel, D. (2014). Why "Gen Z" May Be More Entrepreneurial Than "Gen Y". [Online] https://tech.co/ne ws/gen-z-entrepreneurial-gen-y-2016-02. [Erişim Tarihi: 01. 02. 2020].

Schroer, W. J. (2015). Generations X, Y, Z and the Others. [Online] http://socialmarketing.org/ archives/generations-xy-z-and-the-others/ [Erişim Tarihi: 01. 02. 2020].

Serçek, G. Ö. ve Serçek, S. (2017). X, Y ve Z Kuşaklarındaki Turistlerin Destinasyon İmaj Algılarının Karşılaştırılması, Seyahat ve Otel İşletmeciliği Dergisi, 14(1): 6-19.

Solomon, M. R. (2006). Consumer Behavior: Buying, Having and Being. USA: Prentice Hall.

Southgate, D. (2017). The Emergence of Generation Z and Its Impact in Advertising: Long-Term Implications for Media Planning and Creative Development, Journal of Advertising Research, 57(2): 227-235. 
Styvén, M. E. and Foster, T. (2018). Who am I if You Can't See Me? The "Self" of Young Travellers as Driver of Ewom in Social Media, Journal of Tourism Futures, 4(1): 80-92.

Taş, H. Y., Demirdöğmez, M. ve Küçükoğlu, M. (2017). Geleceğimiz Olan Z Kuşağının Çalışma Hayatına Muhtemel Etkileri, OPUS- Uluslararası Toplum Araştırmaları Dergisi, 7(13): 1031-1048.

Taylor, P. and Keeter, S. (Eds.) (2010). Millennials: A Portrait of Generation Next. Confident, Connected, Open to Change, Washington DC: Pew Research Center.

Tomić, N., Kovačević, B., Berber, N. and Milić, N. (2014). Factors Influencing the Motivation of Young People When Choosing a City Destination in Europe-A Case Study from Esbjerg (Denmark), European Researcher, 2(2): 414-428.

Torun, Y. ve Çetin, C. (2015). Örgütsel Sinizmin Kuşaklar Bazında Değerlendirilmesi: Kuşaklara Göre Örgütsel Sinizmin Hedefinde Ne Var?. İş ve İnsan Dergisi, 2(2): 137-146.

Tulgan, B. (2013). Meet Generation Z: The Second Generation within the Giant "Millennial" Cohort, Rainmaker Thinking, http://grupespsichoterapija.lt/wp-content/uploads/2017/09/Gen-ZWhitepaper.pdf. [Erişim Tarihi: 02. 11. 2019].

Türk Dil Kurumu, (TDK), (2019). [Online] http://www.tdk.gov.tr/index.php?otion=com [Erişim Tarihi: 02. 11. 2019].

Veríssimo, M. and Costa, C. (2018). Do Hostels Play A Role in Pleasing Millennial Travellers? The Portuguese Case, Journal of Tourism Futures, 4(1): 57-68.

Vukic, M., Kuzmanovic, M. and Kostic Stankovic, M. (2015). Understanding the Heterogeneity of Generation Y's Preferences for Travelling: A Conjoint Analysis Approach, International Journal of Tourism Research, 17(5): 482-491. DOI: 10.1002/jtr.2015.

Williams, K. C. and Page, R. A. (2011). Marketing to the Generations, Journal of Behavioral Studies in Business, 3(1): 37-53.

Yazıcıoğlu, Y. ve Erdoğan, S. (2004). SPSS Uygulamalı Bilimsel Araştırma Yöntemleri. Ankara: Detay Yayıncilik.

Yeoman, I. (2013). 2050-Tomorrow's Tourism, Annals of Tourism Research, 41: 257-258.

Yoon, Y. and Uysal, M. (2005). An Examination of the Effects of Motivation and Satisfaction on Destination Loyalty: A Structural Model, Tourism Management, 26(1): 45-56. 